\title{
Two new species of groundwater amphipods of the genus Niphargus Schiödte, 1849 from northwestern Iran
}

\author{
Mahmoud MAMAGHANI-SHISHVAN ${ }^{1} \&$ Somayeh ESMAEILI-RINEH ${ }^{2, *}$ \\ ${ }^{1,2}$ Department of Biology, Faculty of Science, Razi University, Kermanshah, Iran. \\ *Corresponding author: sesmaeili@razi.ac.ir \\ ${ }^{1}$ Email: mamaghani_sh@yahoo.com. \\ ${ }^{1}$ urn:1sid:zoobank.org:author:92B782A2-2BD7-4FD6-B6BD-39A701A1B46B \\ ${ }^{2}$ urn:1sid:zoobank.org:author:8915112A-E4BB-4EC6-AD6E-7F706CDC331E
}

\begin{abstract}
This study was conducted to describe and illustrate two new species of groundwater amphipods from the northern parts of the Zagros Mountains in West Azerbaijan Province, Iran. Mitochondrial (COI) and nuclear (28S rDNA) fragments as well as several morphological traits were used to characterize Niphargus urmiensis sp. nov. and Niphargus fiseri sp. nov. The phylogenetic analyses showed that the nucleotide differences between the recently described species and their close allies are attributed to their distinctiveness. The molecular analysis also introduced that the new species are placed within the clade comprising Iranian species as a sister taxon. The genetic distances between N. urmiensis sp. nov. and $N$. fiseri sp. nov. are $7.6 \%$ and $1.6 \%$, respectively based on the COI and $28 \mathrm{~S}$ rDNA gene fragments.
\end{abstract}

Keywords. 28S rDNA and COI genes, morphological data, new niphargids, taxonomy, West Azerbaijan Province.

Mamaghani-Shishvan M. \& Esmaeili-Rineh S. 2019. Two new species of groundwater amphipods of the genus Niphargus Schiödte, 1849 from northwestern Iran. European Journal of Taxonomy 546: 1-23.

https://doi.org/10.5852/ejt.2019.546

\section{Introduction}

Groundwater accounts for about $40 \%$ of inland water in the world (Castany 1982), containing habitats which are narrowly distributed with a high endemism and a high diversity of fauna communities (Humphreys 2006; Asmyhr et al. 2014; Glanville et al. 2016). Groundwater fauna involve nearly all main taxonomic groups examined in surface waters, but, unfortunately, are poorly surveyed (Deharveng et al. 2009).

It is important to understand species delimitation especially in groups which are common in groundwater habitats (Witt et al. 2006). In these environments, convergent selective pressures result in cryptic speciation (Jörger \& Schrödl 2013). Therefore, cryptic species are difficult to distinguish based on morphological characteristics. Recently, increasing use of molecular techniques in taxonomy has resulted in detecting cryptic species, especially in underground groups (Eme et al. 2017; Stokkan et al. 2018). 
Most of the groundwater animals within crustaceans belong to Niphargus Schiödte, 1849, which is one of the most various and species-rich taxa in groundwater habitats in the Western Palearctic (Väinölä et al. 2008; Fišer et al. 2009a). The members of this taxon inhabit subterranean waters and represent a part of the groundwater biodiversity (Fišer et al. 2007; Brad et al. 2015).

In terms of biodiversity richness, Iran is considered an extremely complex area with extreme distributions in terms of altitude, climate and temperature (Frey \& Probst 1986). The high biodiversity of the Iranian fauna is also the result of its location and influences of four ecozones (Palaearctic, Nearctic, Afrotropical and Oriental) (Madjnoonian et al. 2005). Iran is located in the eastern part of the geographical range of the genus Niphargus. The first species reported from Iran was N. valachicus (Karaman, 1998). Up to now, 18 species have been described from north (two species), west (13 species), northwest (two species) and south (one species) (Karaman 1998; Esmaeili-Rineh et al. 2015a, 2016, 2018; MamaghaniShishvan et al. 2017). Despite the large groundwater aquifers in Iran, the study of these taxonomic groups in those environments is a rather new scientific field. Obviously, most of these species have been identified from various parts of the Zagros Mountains in western Iran.

Some important factors influence the frequency of niphargid populations, including the underlying geology, annual precipitation and the quality of water resources, especially in the karstic areas (White 2007). Climatic and hydrological conditions in northwest Iran (Raeisi 2004) are well suited for members of the genus Niphargus. Until now, no comprehensive research has been conducted in northwestern Iran and only N. khwarizmi Hekmatara, Zakšek, Heidari \& Fišer, 2013 and N. hosseiniei Esmaeili-Rineh, Sari, Fišer \& Bargrizaneh, 2017 have been described from the Kahriz and Brolan Springs in this region, respectively. Both species are widely distributed and endemic to Iran.

In this paper, the results of a recent research on the niphargid fauna from West Azerbaijan in the northwest of Iran are presented, and two new species identified in this region are described according to morphology and two mitochondrial (COI) and nuclear genes (28S rDNA).

\section{Material and methods}

\section{Morphological and morphometric studies}

The samples were provided from Badin Abad and Randole Springs in West Azerbaijan Province, Iran (Fig. 1). The material was collected using a hand net. Badin Abad and Randole Springs are located respectively in the proximity of Piranshahr and near to Oshnavieh in West Azerbaijan. The distance between the localities is about $4.3 \mathrm{~km}$ in a straight line. The material was examined morphologically and mounted on slides in Euparal ${ }^{\circledR}$ medium.

An Olympus LABOMED iVu7000 camera fitted on a LABOMED Lx500 stereo microscope was used to take the digital photos. The computer program ProgRes Capture Pro ver. 2.7 was used to perform the measurements and the counts (Fišer et al. 2009b). The morphological details were analyzed, carefully following Fišer et al. (2009b). According to Karaman (2018), the morphological terminology of setae on the mandibular palpus article 3 and in the propodus of gnathopods I-II was formulated. All material was deposited in the Zoological Collection, Razi University (ZCRU).

\section{Phylogenetic analyses and molecular divergence}

The total genomic DNA was extracted from a part of the animal using Tissue Kits (GenNet Bio ${ }^{\mathrm{TM}}$ ) following the manufacturer's instructions to perform the molecular analyses (Seoul, Korea). The modified primer pair LCO1490-JJ and HCO2198-JJ was used to amplify the mitochondrial COI (Astrin \& Stüben 
2008). The first fragment of $28 \mathrm{~S}$ ribosomal DNA (rDNA) was amplified and sequenced using the forward primer from Verovnik et al. (2005) and the reverse primer from Zakšek et al. (2007).

Each $25 \mu 1$ reaction contained optimized amounts of PCR water, $12.5 \mu 1$ of Master Mix kit (Sinaclon, Iran), $0.2 \mu \mathrm{l}$ of each primer $(10 \mu \mathrm{M})$, and 50-100 ng of genomic DNA template. An initial denaturation step at $94^{\circ} \mathrm{C}$ for three minutes was followed by 36 cycles of 40 seconds at $94^{\circ} \mathrm{C}, 40$ seconds at $52.5^{\circ} \mathrm{C}$ and two minutes at $65^{\circ} \mathrm{C}$, with a final extension step for eight minutes at $65^{\circ} \mathrm{C}$ to amplify the COI gene. Cycling parameters for the 28S rDNA gene were as follows: initial denaturation of $94^{\circ} \mathrm{C}$ for seven minutes, 35 subsequent cycles of $94^{\circ} \mathrm{C}$ for 45 seconds, $55^{\circ} \mathrm{C}$ for 30 seconds, $72^{\circ} \mathrm{C}$ for one minute, and a

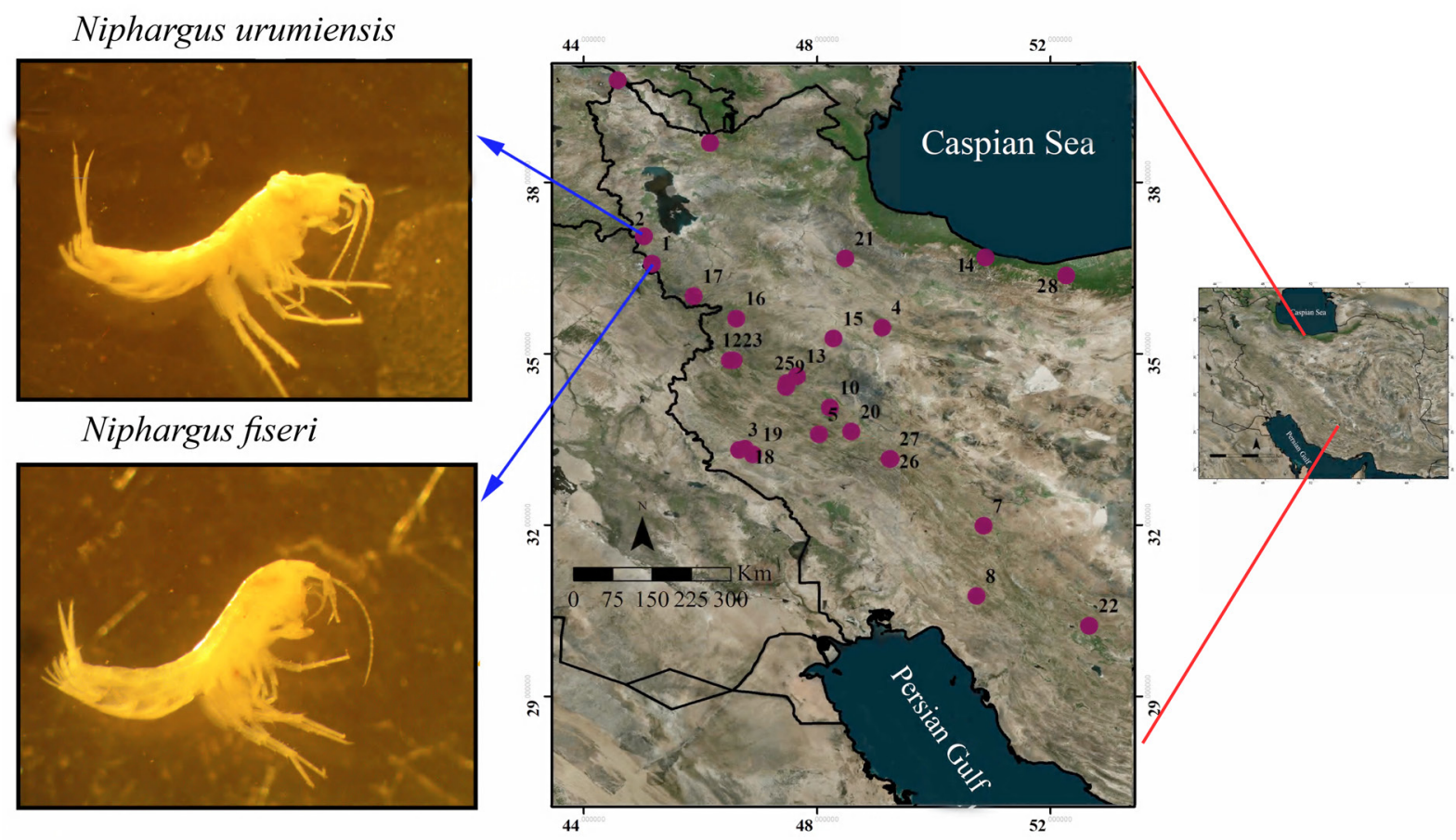

Fig. 1. Distribution map of the species of Niphargus Schiödte, 1849 in Iran. Localities are labelled as: 1. N. fiseri sp. nov. 2. N. urmiensis sp. nov. 3. N. sarii Esmaeili-Rineh, Mohammad-Niakan \& Akmali, 2018. 4. N. hakani Esmaeili-Rineh, Mirghaffari \& Sharifi, 2017. 5. N. sharifii Esmaeili-Rineh, Sari \& Fišer, 2015. 6. N. darvishi Esmaeili-Rineh, Sari \& Fišer, 2015. 7. N. borisi Esmaeili-Rineh, Sari \& Fišer, 2015 (Siah population). 8. N. borisi (Belqais population). 9. N. bisitunicus EsmaeiliRineh, Sari \& Fišer, 2015. 10. N. khwarizmi Hekmatara, Zakšek, Heidari \& Fišer, 2013 (Sarab-e-Niaz). 11. N. khwarizmi (Kahriz population). 12. N. khayyami Hekmatara, Zakšek, Heidari Baladehi \& Fišer, 2013. 13. N. kermanshahi Esmaeili-Rineh, Heidari, Fišer \& Akmali, 2016. 14. N. daniali EsmaeiliRineh \& Sari, 2013. 15. N. alisadri Esmaeili-Rineh \& Sari, 2013. 16. N. kurdistanensis Hekmatara, Zakšek, Heidari Baladehi \& Fišer, 2013 (Darvish-Olya population). 17. N. kurdistanensis (Shoei population). 18. N. ilamensis Esmaeili-Rineh, Sari, Fišer \& Bargrizaneh, 2017 (Sarab-e-Kanipahn). 19. N. ilamensis (Sarab-e-Mord). 20. N. sohrevardensis Esmaeili-Rineh, Sari, Fišer \& Bargrizaneh, 2017 (Razbashi population). 21. N. sohrevardensis (Sohrevard population). 22. N. persicus EsmaeiliRineh, Sari, Fišer \& Bargrizaneh, 2017. 23. N. hosseiniei Esmaeili-Rineh, Sari, Fišer \& Bargrizaneh, 2017 (Ghori-Ghale population). 24. N. hosseiniei (Brolan population). 25. N. hosseiniei (Nojivaran population). 26. $N$. lorestanensis Esmaeili-Rineh, 2018 (Shol-Abad population). 27. N. lorestanensis (Ab-rahmeh population). 28. N. valachicus (Karaman, 1998). 
final extension of $72^{\circ} \mathrm{C}$ for seven minutes. The purified PCR products were sequenced commercially by Macrogen Inc., Korea. Sequencing was performed using both primers mentioned above.

The acquired sequences (with GenBank accession numbers MK911603 to MK911612) were analyzed within the data set by Esmaeili-Rineh et al. (2015b), to identify the phylogenetic position of the newly discovered materials. The NCBI available sequences for three species, Synurella ambulans (F. Müller, 1846), Pontogammarus crassus (Sovinsky, 1904) and Gammarus fossarum Koch, 1836, were used as outgroups (accession numbers: KF719240, KF719242 and KF71924). All sequences were edited and aligned using ClustalW (Thompson et al. 1994), as implemented in Bioedit ver. 7.0.5.3 program sequence alignment editor (Hall 1999) using the default settings. Alignments were concatenated and jModelTest ver. 0.1.1 (Posada 2008) was used under the Akaike information criterion (AIC) to select the optimal substitution model for each partition. The optimal substitution models were GTR $+\Gamma$ and $\mathrm{GTR}+\mathrm{I}+\Gamma$ for $28 \mathrm{~S}$ and COI genes, respectively.

The phylogenetic form was reconstructed using the Bayesian inferences in Mr Bayes ver. 3.1.2 (Ronquist \& Huelsenbeck 2003). Bayesian analyses were implemented for five million generations, with four chains, and the trees were sampled every 1000 generations. The first 1250 sampled trees were discarded as burn-in, and the subsequent tree likelihoods were examined for convergence in Tracer program ver. 1.5.0 (Rambaut \& Drummond 2009). The remaining trees visualized by FigTree ver. 1.4.0 were applied to calculate a $50 \%$ majority rule consensus tree. The data on analyzed species are available in the Electronic Supplement of Esmaeili-Rineh et al. (2015b, 2017a, 2017b). The corrected genetic distances were calculated using Kimura two-parameter (K2P) model (Kimura 1980) as implemented in MEGA ver. 5 software to measure the divergence from other, already described Iranian species of Niphargus (Tamura et al. 2011).

\section{Results}

\section{Phylogenetic position of the new species and their genetic distinctness}

The dataset used in phylogenetic analyses comprised individuals from Iran and a single specimen from Lebanon constituting a monophyletic group. According to Esmaeili-Rineh et al. (2015b), the eastern half of the genus range was colonized several times independently and constitutes an unresolved relationship to other European species of Niphargus.

A total of five individuals, two from Randole and three from Badin Abad Springs were sequenced and analyzed. The two specimens from the Randole population indicated unique haplotypes in terms of both fragments of COI (513 bp) and 28S (954 bp) genes. However, the three specimens from the Badin Abad population showed three and two haplotypes based on the COI and $28 \mathrm{~S}$ genes, respectively. The phylogenetic analyses on 43 specimens consistently led to the placement of the two new species into a clade with a sister relationship within the Middle East clade. The precise position of this clade is unknown within the Middle East clade. The phylogenetic relationships between this clade (the two new species) and other clades in the Middle East clade were mostly not resolved according to the combined data of $28 \mathrm{~S}$ and COI gene fragments (1467 bp) (Fig. 2).

The two new species are obviously different from all other Iranian species. Table 1 shows the pairwise Kimura two parameter genetic distances between $N$. urmiensis sp. nov., $N$. fiseri sp. nov. and all other species for two genes. Niphargus urmiensis sp. nov. is the most genetically similar species to $N$. fiseri sp. nov. (7.6\% and 1.6\% in the studied COI and 28S rDNA genes fragment) and the most divergent species from $N$. daniali Esmaeili-Rineh \& Sari, 2013 (18.6\% and 10\% based COI and 28S rDNA genes). In addition, the least genetic divergence to $N$. fiseri sp. nov. was observed in $N$. urmiensis sp. nov. (7.6\%) and N. alisadri Esmaeili-Rineh \& Sari, 2013 (1.3\%) for COI and 28S rDNA, respectively. Also, N. fiseri 


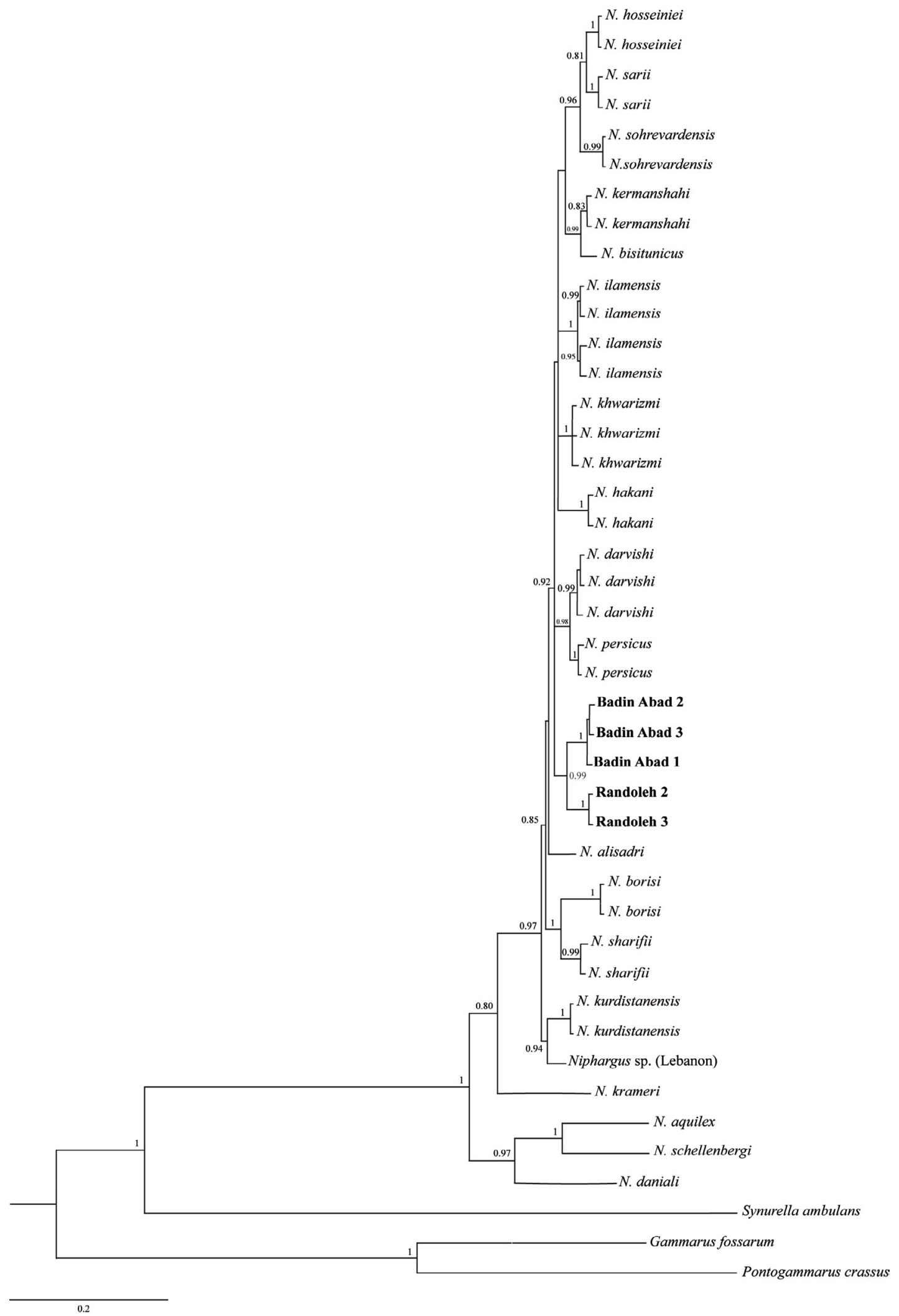

Fig. 2. Bayesian tree of 43 specimens as inferred from the $28 \mathrm{~S}$ and COI gene sequences. Species are identified and named according to available taxonomic descriptions. Bayesian posterior probabilities more than 0.8 are indicated above branches. 


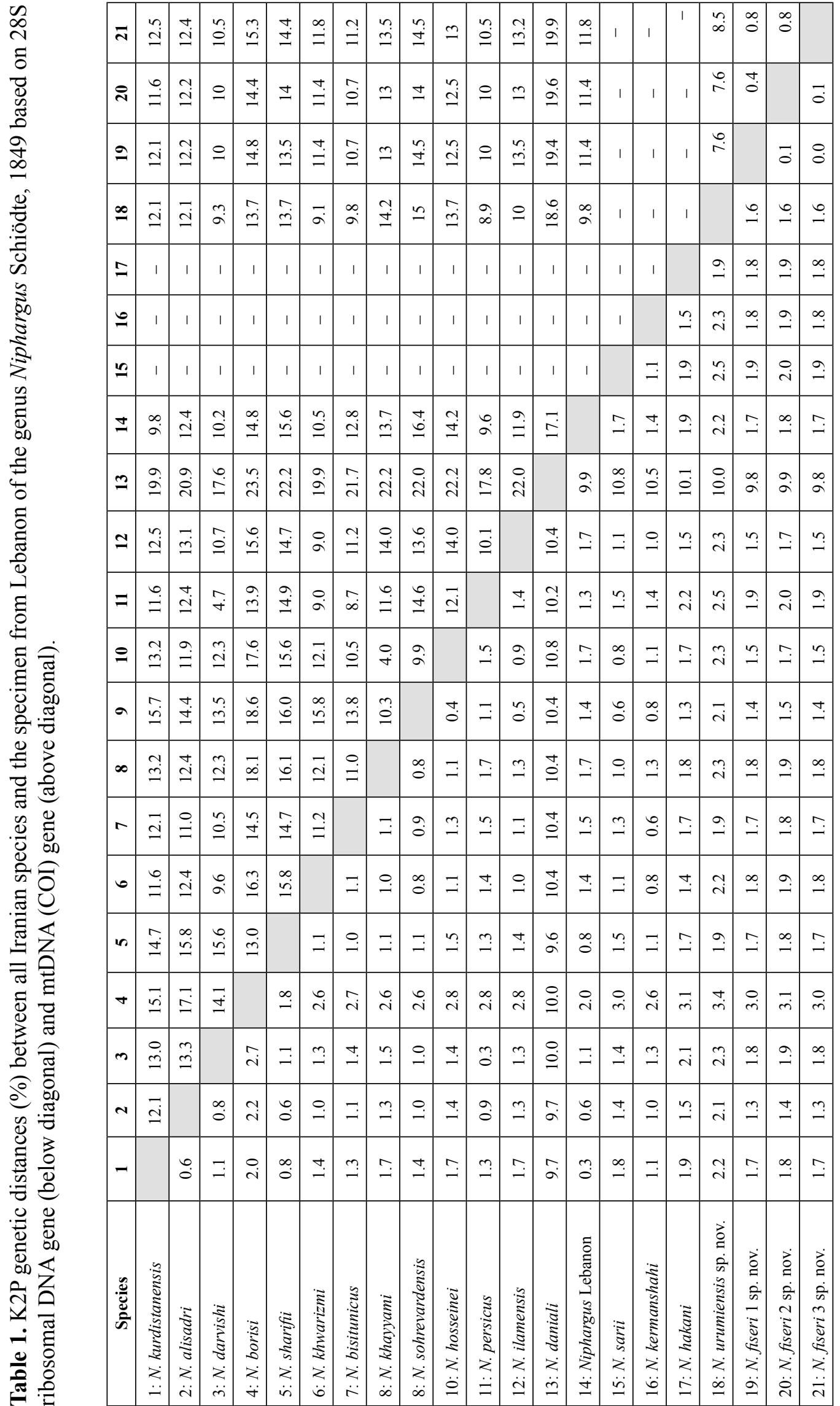


sp. nov. indicate the most genetically divergent species from $N$. daniali $(19.9 \%$ and $9.9 \%$ in the studied COI and 28S rDNA genes fragment).

\title{
Species description
}

\author{
Order Amphipoda Latreille, 1816 \\ Family Niphargidae Bousfield, 1977 \\ Genus Niphargus Schiödte, 1849 \\ Niphargus urmiensis sp. nov. \\ urn:1sid:zoobank.org:act:7C655030-3855-4B46-85D1-76DB596428AA
}

Figs 1, 3-6

Diagnosis (based on male only)

The palpus of maxilla I is short and does not reach the tip of the outer lobe. The size of coxae in gnathopods I and II is sub-similar. Gnathopods bear trapezoidal to rectangular shape of propodi. Gnathopds I to II dactyli have a single seta on the outer margin. Dorso-laterally, the urosomites I to II bear one and two setae, respectively. The inner ramus in uropod I is longer than the outer ramus. Epimeral plates I-II are partly angular but not produced. Lobes of telson have three distal spines each and no lateral spines. The telson cleft is more than half its length.

\section{Etymology}

The name 'urmiensis' refers to Urmia City, the center of West Azerbaijan province (Iran), where the species was found.

\section{Material examined}

\section{Holotype}

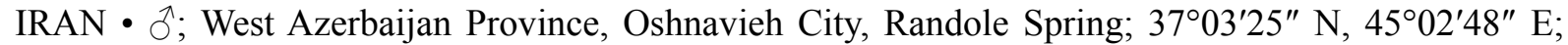
10 Jul. 2016; M. Mamaghani-Shishvan leg.; ZCRU Amph.1071.

\section{Paratypes}

IRAN $\bullet 1$ त, 1 juv. (body length 6.8 and $3.8 \mathrm{~mm}$, respectively); same data as for holotype; ZCRU Amph.1071.

\section{Description of holotype}

MEASUREMENTS. The total length of the holotype is $8 \mathrm{~mm}$. Head represents $17 \%$ of the total body length (Fig. 3C).

Antennae. Antenna I (Fig. 3A) is 0.51 times body length. Peduncular articles 1-3 progressively shorter; length of peduncular article 3 exceeds half of peduncular article 2 (ratio $1.00: 1.80$ ). Main flagellum with 18 articles (most with short setae), articles with up to one aesthetasc. Accessory flagellum bi-articulated and reaching $1 / 4$ of article 4 of main flagellum; both articles with two and one setae, respectively. Antenna II with flagellum formed of seven articles, approximately half as long as antenna I. Flagellum length is 0.79 times length of peduncle articles $4+5$. Peduncular article 4 of antenna II is longer than article 5 $(1.3: 1.00)$, peduncle articles 4 and 5 with seven and five groups of setae, respectively (Fig. 3B).

Mouth PARTS. Labium (Fig. 4C) bi-lobate; with fine setae on tip of outer lobes. Inner plate of maxilla I with two long apical setae, outer plate with seven long spines with 0-3-1-3-0-0-2 lateral projections; palp bi-articulated, short and not reaching tip of outer lobe, with seven apical setae (Fig. 3D-E). Both plates of maxilla II with numerous long distal and lateral setae (Fig. 4E). Mandible: right mandible with 


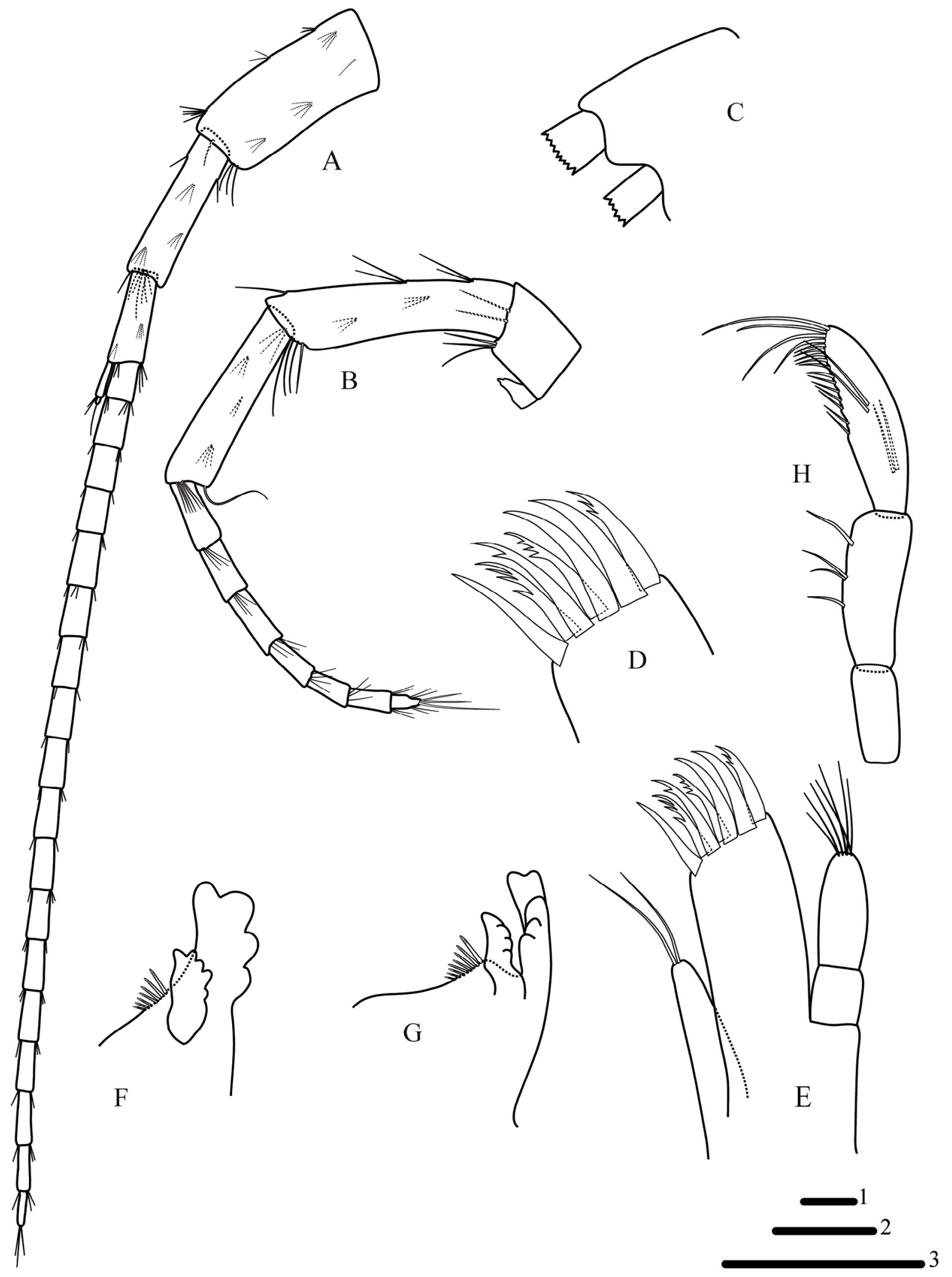

Fig. 3. Niphargus urmiensis sp. nov., holotype, $\widehat{\partial}, 8 \mathrm{~mm}$ (ZCRU Amph.1071). A. Antenna I. B. Antenna II. C. Head. D-E. Maxilla I. F. Left mandible. G. Right mandible. H. Mandibular palp. Scale bars: $1=0.25 \mathrm{~mm}(\mathrm{~F}-\mathrm{G}) ; 2=0.5 \mathrm{~mm}(\mathrm{C}-\mathrm{E}) ; 3=1 \mathrm{~mm}(\mathrm{~A}-\mathrm{B})$. 

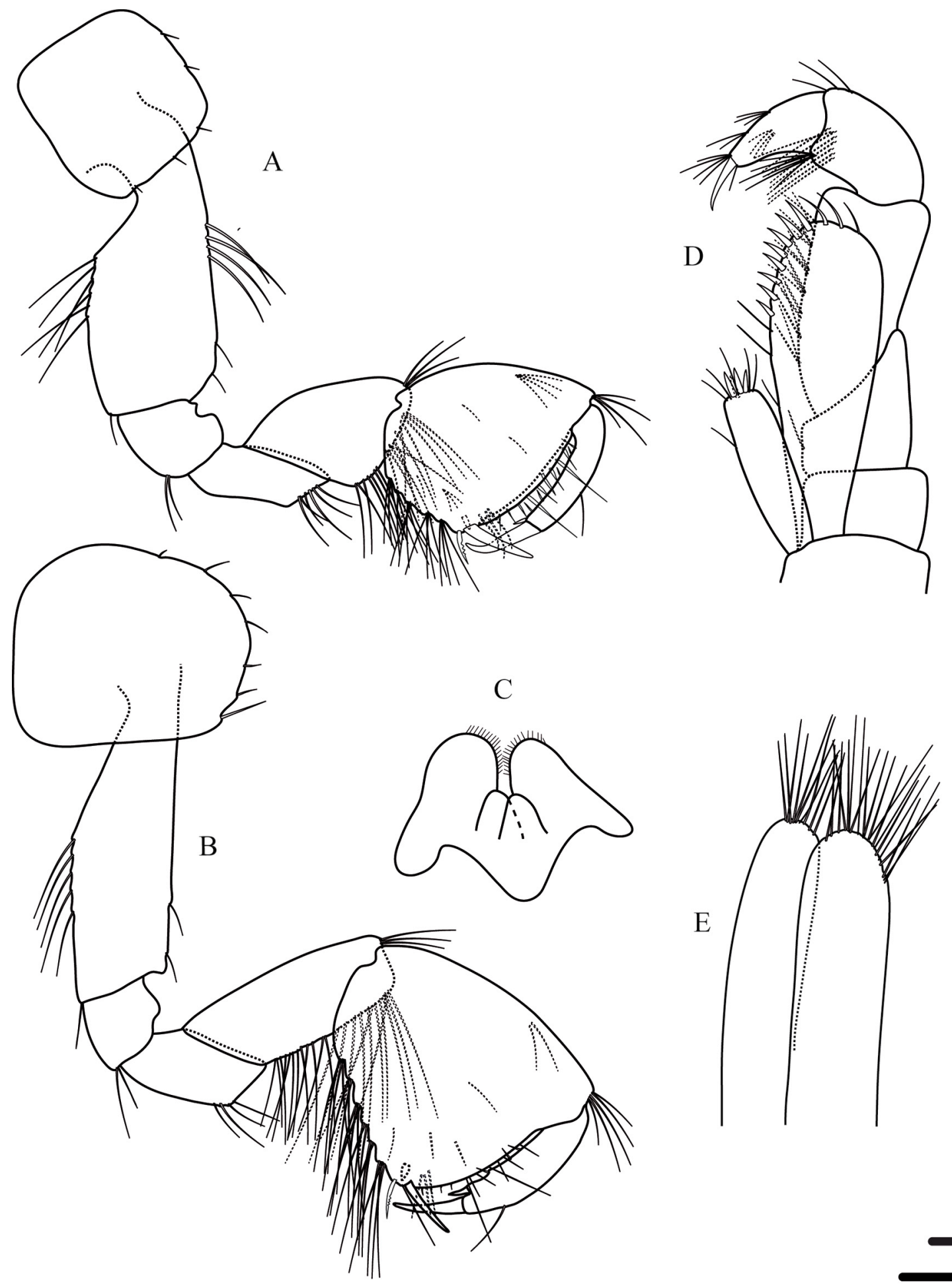

Fig. 4. Niphargus urmiensis sp. nov., holotype, $\hat{\jmath}, 8 \mathrm{~mm}$ (ZCRU Amph.1071). A. Gnathopod I. B. Gnathopod II. C. Labium. D. Maxilliped. E. Maxilla II. Scale bars: $1=0.5 \mathrm{~mm}(\mathrm{C}-\mathrm{E}) ; 2=1 \mathrm{~mm}$ (A-B). 
four teeth on incisor process, lacinia mobilis pluritoothed and row of seven setae with lateral projections (Fig. 3F). Left mandible with five teeth on incisor process, lacinia mobilis with four teeth and row of eight setae with lateral projections (Fig. 3G). Mandibular palp articles 1:2:3 represent 20\%, 31\% and $49 \%$ of total palp length, respectively. Proximal article without setae; second article with four setae along inner margin and third article with one group of two A-setae, one group of B-setae, no C-setae, 12 D-setae and four E-setae (Fig. 3H). Maxilliped with short inner plate bearing four distal spines intermixed with five distal setae and one long lateral seta sub-distally; outer plate exceeding half of palp article 2, with eight spines along inner margin and three setae distally; maxilliped palp article 3 at outer margin with one proximal and one distal group of long setae; palp terminal article with three groups of setae at outer margin and one seta at base of nail, nail shorter than pedestal (Fig. 4D).

GNATHOPODS. Coxal plates of gnathopods I-II almost equal in size. Coxa of gnathopod I rectangular, longer than broad, anterior and ventral margins with five marginal setae. Basis with setae on anterior and posterior margins; ischium and merus with posterior group of setae. Carpus with one group of three setae antero-distally, bulge with long setae; carpus 0.55 times basis length and 0.87 times propodus length. Propodus of gnathopod I trapezoid shape and broader than long; anterior margin with four setae in one group in addition to antero-distal group of four setae. Palm convex, defined on outer surface by one strong long corner S-seta accompanied laterally by one L-seta with lateral projections and row of three facial M-setae, on inner surface by one short sub-corner R-seta. Dactylus reaching posterior margin of propodus, outer and inner margins of dactylus with one and four setae, respectively. Nail length 0.35 times total dactylus length (Fig. 4A). Coxal plate of gnathopod II with rectangular shape, longer than broad, anterior and ventral margins with seven setae. Basis with setae on anterior and posterior margins; ischium and merus with posterior group of setae. Carpus with one group of three setae antero-distally, bulge with long setae; carpus 0.69 times basis length and 0.85 times propodus length. Propodus longer than broad; anterior margin with two setae in one group in addition to antero-distal group of five setae. Palm slightly convex, defined on outer surface by one strong, long corner S-seta accompanied laterally by one L-seta with lateral projections and row of three facial M-setae, on inner surface by one short subcorner R-seta. Dactylus reaching posterior margin of propodus, outer and inner dactylar margins with one and three setae, respectively; nail short, 0.28 times total dactylus length (Fig. 4B). Coxal plate III rectangular, length to width ratio is $1.08: 1$; antero-ventro-posterior margin with six setae. Coxal plate IV rectangular, antero-ventral margin with four setae, posterior concavity shallow and approximately 0.1 times coxa width (Fig. 5A-B). Coxal plate $\mathrm{V}$ with five and one setae on anterior and posterior lobes, respectively. Coxal plate VI with one simple seta on posterior lobe. Coxal plate VII with one simple seta (Fig. 5C-E).

Pereopods. Pereopod III :IV length ratio is $1.05: 1$ (Fig. 5A-B). Dactylus IV short, dactylus length 0.54 times propodus length, nail shorter than pedestal (Fig. 5B). Pereopods V:VI: VII length ratios $1: 1.17: 1.22$, respectively. Pereopod VII is 0.53 times total body length. Pereopod bases V-VI each with six groups of spines along anterior margins and with eight and seven setae along posterior margins, respectively. Pereopod basis VII with six groups of spines along anterior margin and seven setae along posterior margin, respectively (Fig. 5C-E). Postero-ventral lobe of ischium in pereopods V-VII developed. Ischium, merus and carpus in pereopods V-VII with several groups of spines and setae along anterior and posterior margins; propodus of pereopod VI longer than these in V and VII, dactyli of pereopods V-VII with one spine and one short seta at base of nail on inner margin, nail length of pereopod VII 0.3 times total dactylus length (Fig. 5C-E).

EPIMERAL PLATES I-III (Fig. 6G). With angular postero-ventral corner, postero-ventral corners of plates I-III posteriorly with two, three and three spines and setae, respectively. Epimeral plates II-III with one and two spines along of ventral margins, respectively. 
PleOPODS. Peduncle of pleopods I-III with two-hooked retinacles at distal part of inner margins. Peduncle of pleopod I with one seta along of outer margin. Peduncle of pleopod III with two setae along of inner margin (Fig. 6A-C); rami of pleopods I-III each with five to eight articles (Fig. 6A-C).
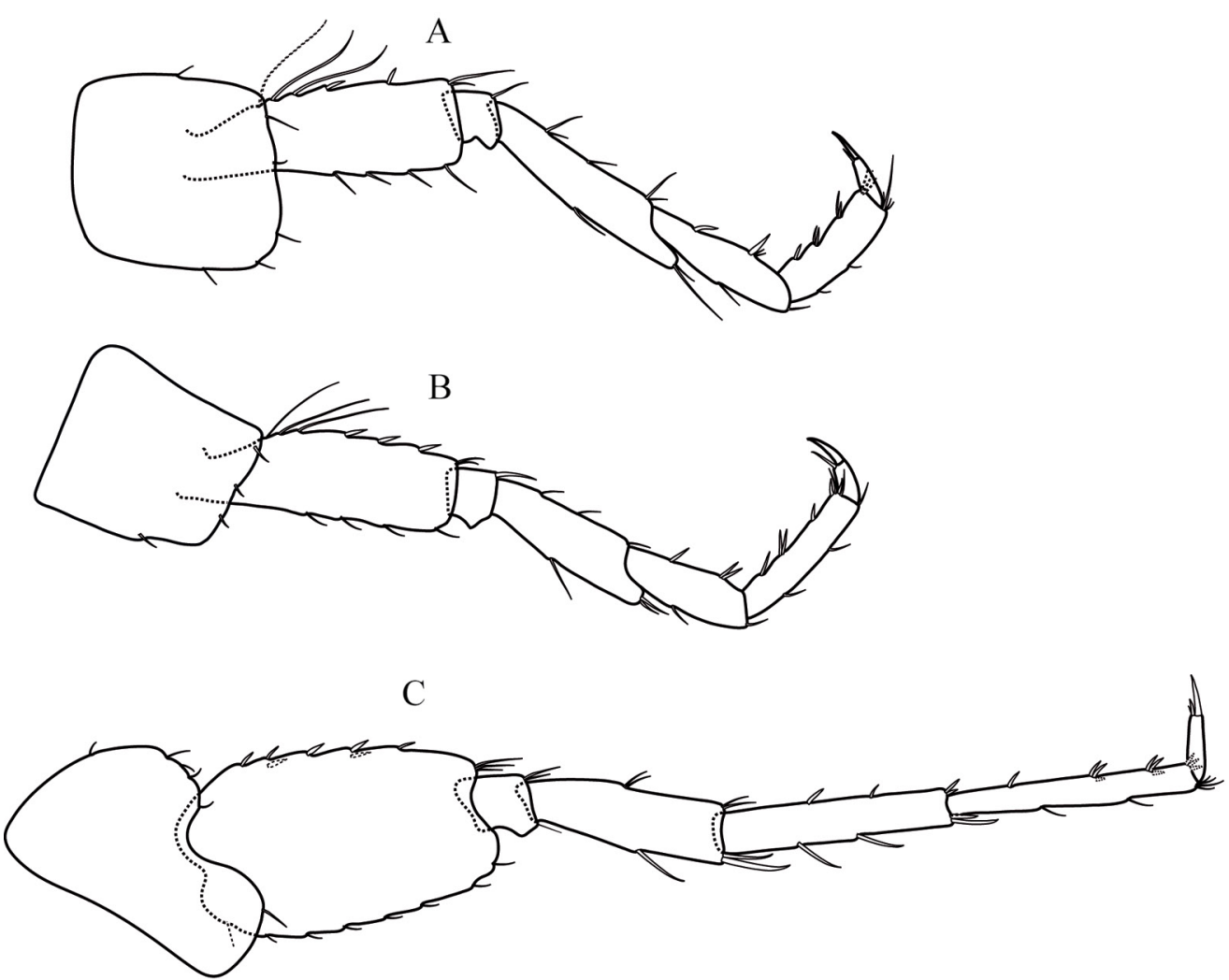

$\mathrm{D}$
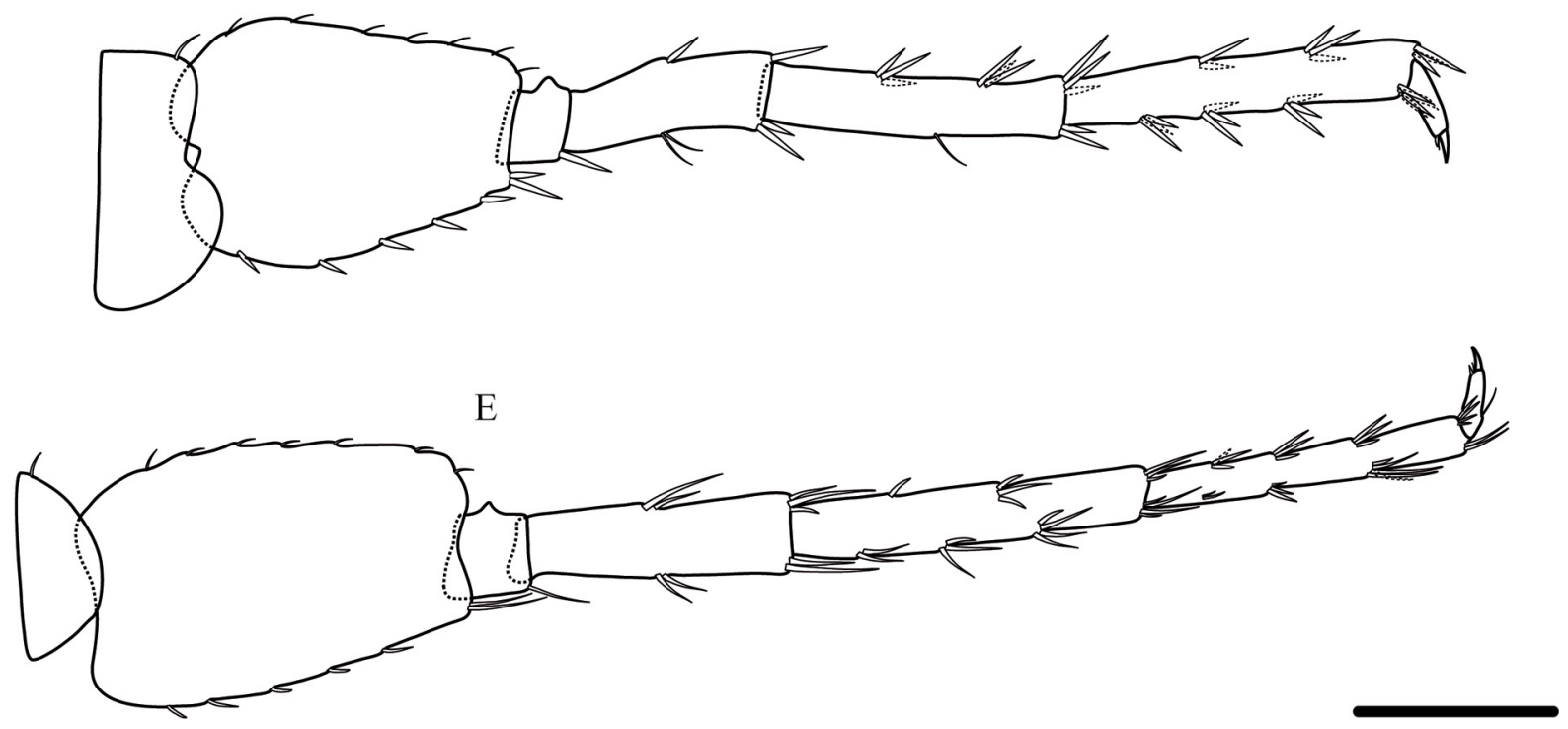

Fig. 5. Niphargus urmiensis sp. nov., holotype, $\widehat{\jmath}, 8 \mathrm{~mm}$ (ZCRU Amph.1071). A. Pereopod III. B. Pereopod IV. C. Pereopod V. D. Pereopod VI. E. Pereopod VII. Scale bar: 1 mm. 


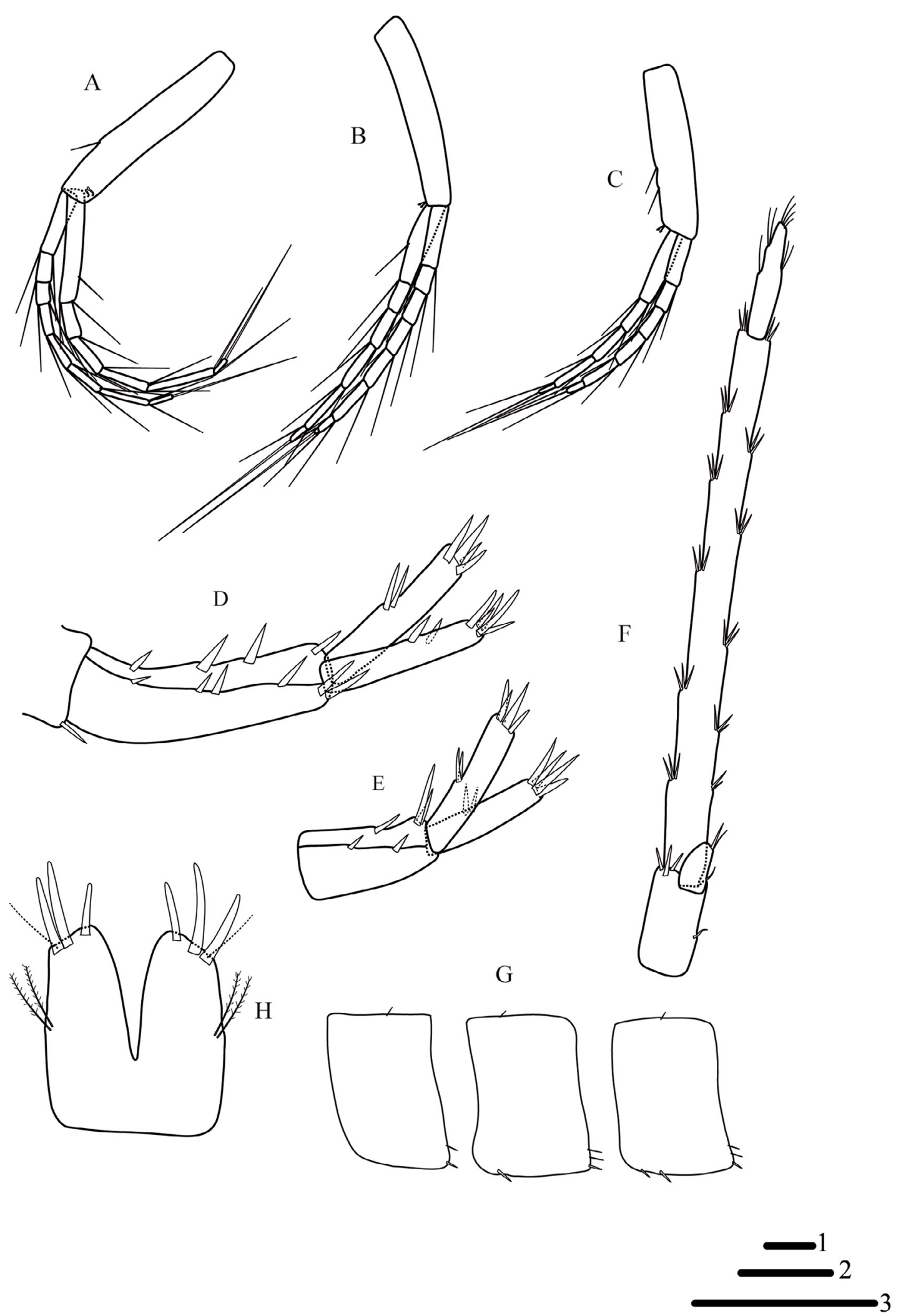

Fig. 6. Niphargus urmiensis sp. nov., holotype, ${ }^{\lambda}, 8 \mathrm{~mm}$ (ZCRU Amph.1071). A. Pleopod I. B. Pleopod II. C. Pleopod III. D. Uropod I. E. Uropod II. F. Uropod III. G. Epimeral plates. H. Telson. Scale bars: $1=0.5 \mathrm{~mm}(\mathrm{G}-\mathrm{H}) ; 2=1 \mathrm{~mm}(\mathrm{~A}-\mathrm{E}) ; 3=2 \mathrm{~mm}(\mathrm{~F})$. 
Pereonites. Pereonites I-VII without setae. Pleonites I-III each with one seta in middle of article on dorsal margin. Urosomites I-II with one and two setae on dorso-lateral margin, respectively. Urosomite III without setae. Urosomite I with one spine at base of uropod I.

URopods. Peduncle of uropod I with six and four large spines along dorso-lateral and dorso-medial margins, respectively. Outer ramus of uropod I slightly shorter than inner ramus (ratio 1:1.06); inner ramus with one group of two spines laterally and four spines distally; outer ramus with two groups of two spines laterally and five spines distally (Fig. 6D). Inner ramus in uropod II longer than outer, both rami with lateral and distal long spines (Fig. 6E). Uropod III long, almost 0.42 times body length. Peduncle of uropod III with three spines, outer ramus bi-articulated, distal article 0.26 times proximal article. Proximal article of outer ramus bearing each six groups of spines along inner and outer margins (Fig. 6F); distal article with setae laterally and four setae distally. Inner ramus short, with one distal spine and one lateral seta. Telson longer than broad, lobes slightly narrowing; each lobe with three spines and one seta distally, with two plumose setae laterally (Fig. 6H).

\section{Female}

Unknown.

\section{Remarks}

Niphargus urmiensis sp. nov. is characterized by two traits. The first one is the presence of one spine with lateral projections on the outer surface of the palmar corner in gnathopods I-II propodi. This character has been reported in N. bisitunicus Esmaeili-Rineh, Sari \& Fišer, 2015 and $N$. fiseri sp. nov., however, both latter species bear the lateral spines in each telson lobe. Also, the maxillar palpus in $N$. urmiensis sp. nov. is short and not reaching the tip of the outer lobe of maxilla I, this character is rare among niphargids, but it has been reported in N. kermanshahi Esmaeili-Rineh, Heidari, Fišer \& Akmali, 2016, N. sohrevardensis Esmaeili-Rineh, Sari, Fišer \& Bargrizaneh, 2017, N. borisi Esmaeili-Rineh, Sari \& Fišer, 2015 and N. ilamensis Esmaeili-Rineh, Sari, Fišer \& Bargrizaneh, 2017 from Iran and N. auerbachi Schellenberg, 1934 from Switzerland. Niphargus urmiensis sp. nov., however, differs in the lower numbers of spines on the outer surface of the palmar corner of gnathopods I-II.

Niphargus fiseri sp. nov.

urn:1sid:zoobank.org:act:1C9668BC-69FD-4B1F-B08C-27C92D10EF05

Figs $1,7-10$

Diagnosis (based on male only)

Antenna I is shorter than half of the total body length. The palpus of maxilla I is as long as the outer lobe. The palmar corner of gnathopods I-II has two short supporting spines. Gnathopods I-II bear trapezoidal shape of propodi. Gnathopods I-II dactyli have a single seta on the outer margin. Pereopod VI is longer than pereopod VII. Urosomite I bears one simple seta and urosomite II bears two spines on dorso-lateral margin. The outer ramus in uropod I is shorter than the inner ramus. Epimeral plates I-II are partly pointed. The lobes of the telson bear three distal and one marginal spines. The telson cleft is more than half of the telson length.

\section{Etymology}

The species is named in honor of Dr. Cene Fišer, University of Ljubljana, Slovenia who dedicated his research to the examination and exploration of subterranean amphipod diversity. 


\section{Material examined}

Holotype

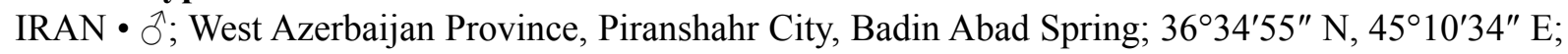
24 Aug. 2016; M. Mamaghani-Shishvan leg.; ZCRU Amph.1073.

\section{Paratypes}

IRAN $\cdot 2$ 9 (body length between 6.8 and $7.5 \mathrm{~mm}$ ); same data as for holotype; ZCRU Amph.1073.

\section{Description of holotype}

MeAsurements. Total male body length is $8 \mathrm{~mm}$. Head reperesents $18 \%$ of total body length (Fig. 7C). Antenna I is 0.39 times body length. Peduncular articles 1-3 progressively shorter; length of peduncular articles 3 exceeds half of peduncular article 2 (ratio 1.21:1); main flagellum with 16 articles (most with short setae), articles with up to one aesthetasc. Accessory flagellum bi-articulated and reaching $1 / 3$ of article 4 of main flagellum, with one and two setae, respectively (Fig. 7A).

AnTENNAE. Antenna II with flagellum formed of seven articles, approximately half as long as antenna I. Flagellum length is 0.90 of length of peduncle article $4+5$. Peduncular article 4 slightly longer than article 5, with seven and five groups of setae, respectively (Fig. 7B).

MOUTH PARTS. Labium (Fig. 8D) bi-lobate; with setae on the tip of lobes. Inner plate of maxilla I with two long apical setae; outer plate with seven spines with 3-2-2-1-0-1-0 lateral projections; palp bi-articulated, as long as outer lobe, with three long apical setae (Fig. 7D-E). Both plates of maxilla II with numerous distal setae and two lateral setae (Fig. 8E). Left mandible with five teeth on incisor process, lacinia mobilis with four teeth and a row of seven setae with lateral projections (Fig. 7F). Right mandible with four teeth on incisor process, lacinia mobilis pluritoothed and row of five setae with lateral projections (Fig. 7G). Mandibular palp articles 1:2:3 represent $22 \%, 35 \%$ and $43 \%$ of total palp length. Proximal article without setae, second article with five setae along inner margin and third article with one group of two A-setae, two groups of B-setae, no C-setae, 17 D-setae and five E-setae (Fig. 7H). Maxilliped with normal inner plate on which four distal spines intermixed with five distal and one simple long lateral setae subdistally; outer plate exceeding half of posterior margin of palp article 2, with nine spines along inner margin and three simple setae distally. Maxilliped palp article 3 with one proximal, inner and outer group of long simple setae at outer margin; palp terminal article with one simple seta at outer margin, nail shorter than pedestal (Fig. 8C).

GNATHOPODS. Gnathopod II larger than gnathopod I. Coxal plate of gnathopod I rounded, broader than long. Coxa I ventral margin with four setae. Basis with setae on anterior and posterior margins; ischium and merus with posterior group of setae. Carpus with one group of three setae antero-distally, bulge with long setae; carpus 0.53 times basis length and 0.88 times propodus length. Propodus longer than broad; anterior margin with three setae in one group in addition to antero-distal group of five setae. Palm slightly convex, defined on outer surface by one strong long corner S-seta accompanied laterally by one L-seta with lateral projections and row of three facial M-setae and by two short sub-corner R-setae on inner surface. Dactylus reaching posterior margin of propodus, outer and inner margins with row of one and two setae, respectively; nail short, 0.45 times total dactylus length (Fig. 8A). Coxal plate of gnathopod II slightly rounded, with five setae along antero-ventro-posterior margins. Basis with setae along anterior and posterior margins; posterior margins of ischium and merus with one posterior group of setae each. Carpus 0.64 times basis length and 0.90 times propodus length. Carpus with one group of two setae antero-distally. Propodus in gnathopod II larger than gnathopod I, rectangular and longer than broad; anterior margin with two setae in one group in addition to antero-distal group of four setae. Palm convex, defined on outer surface by one strong long corner S-seta accompanied laterally by one L-seta with lateral projections and row of three facial M-setae, on inner surface by two short sub-corner 


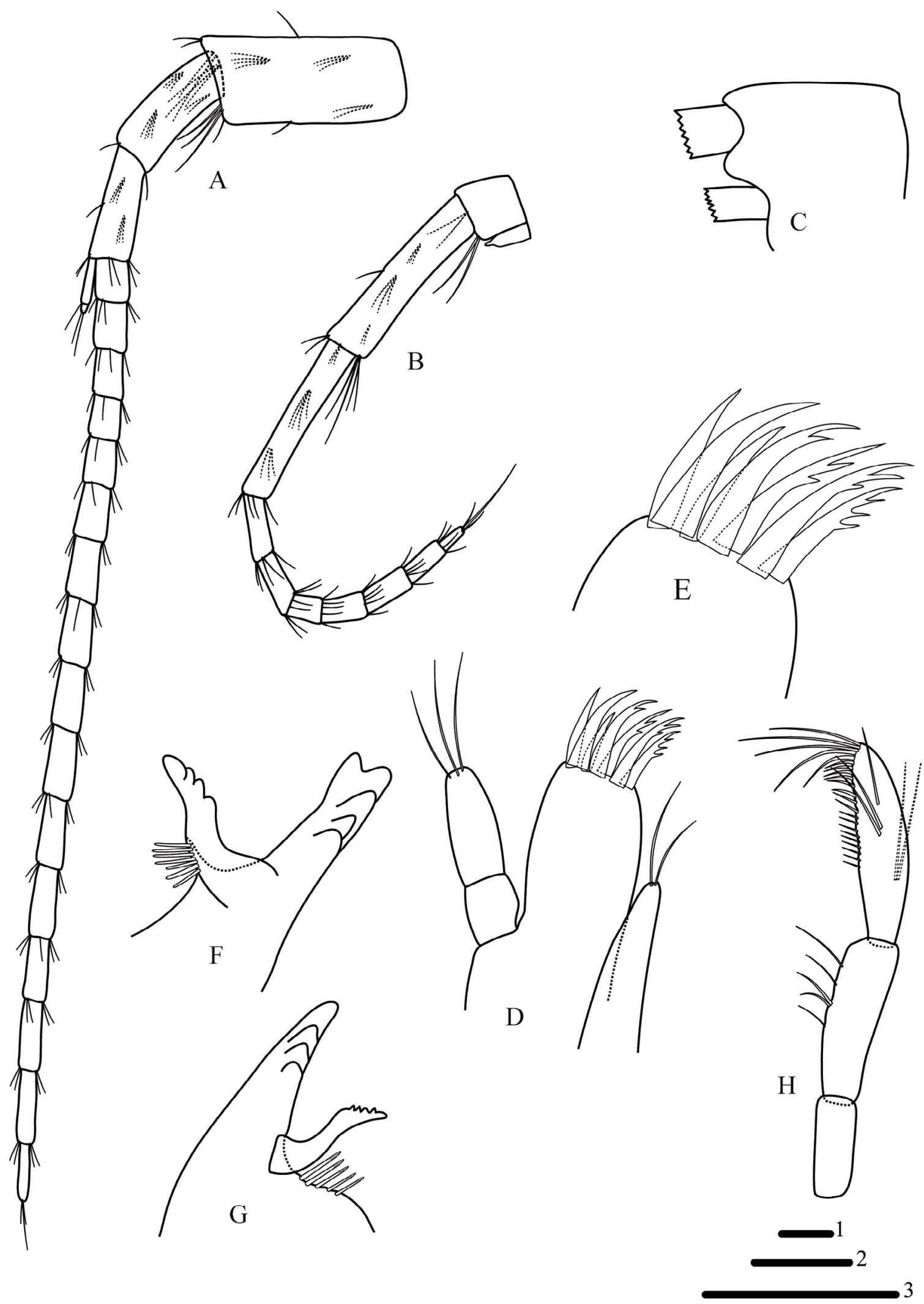

Fig. 7. Niphargus fiseri sp. nov., holotype, $\hat{\jmath}, 8 \mathrm{~mm}$ (ZCRU Amph.1073). A. Antenna I. B. Antenna II. C. Head. D-E. Maxilla I. F. Left mandible. G. Right mandible. H. Mandibular palp. Scale bars: $1=0.25 \mathrm{~mm}(\mathrm{~F}-\mathrm{G}) ; 2=0.5 \mathrm{~mm}(\mathrm{C}-\mathrm{E}, \mathrm{H}) ; 3=1 \mathrm{~mm}(\mathrm{~A}-\mathrm{B})$. 
R-setae. Dactylus reaching posterior margin of propodus, outer and inner margins of dactylus with one and three setae, respectively. Nail length 0.45 of total dactylus length (Fig. 8B). Coxal plate III with rectangular shape, length to width ratio is $1.42: 1$; antero-ventral margin with five setae. Coxal plate IV with rectangular shape, ventral margin with four setae, posterior concavity shallow and approximately 0.1 of coxa width (Fig. 9A-B). Coxal plates V-VI with two and one setae on anterior and posterior lobes, respectively. Coxal plate VII with one seta (Fig. 9C-E).

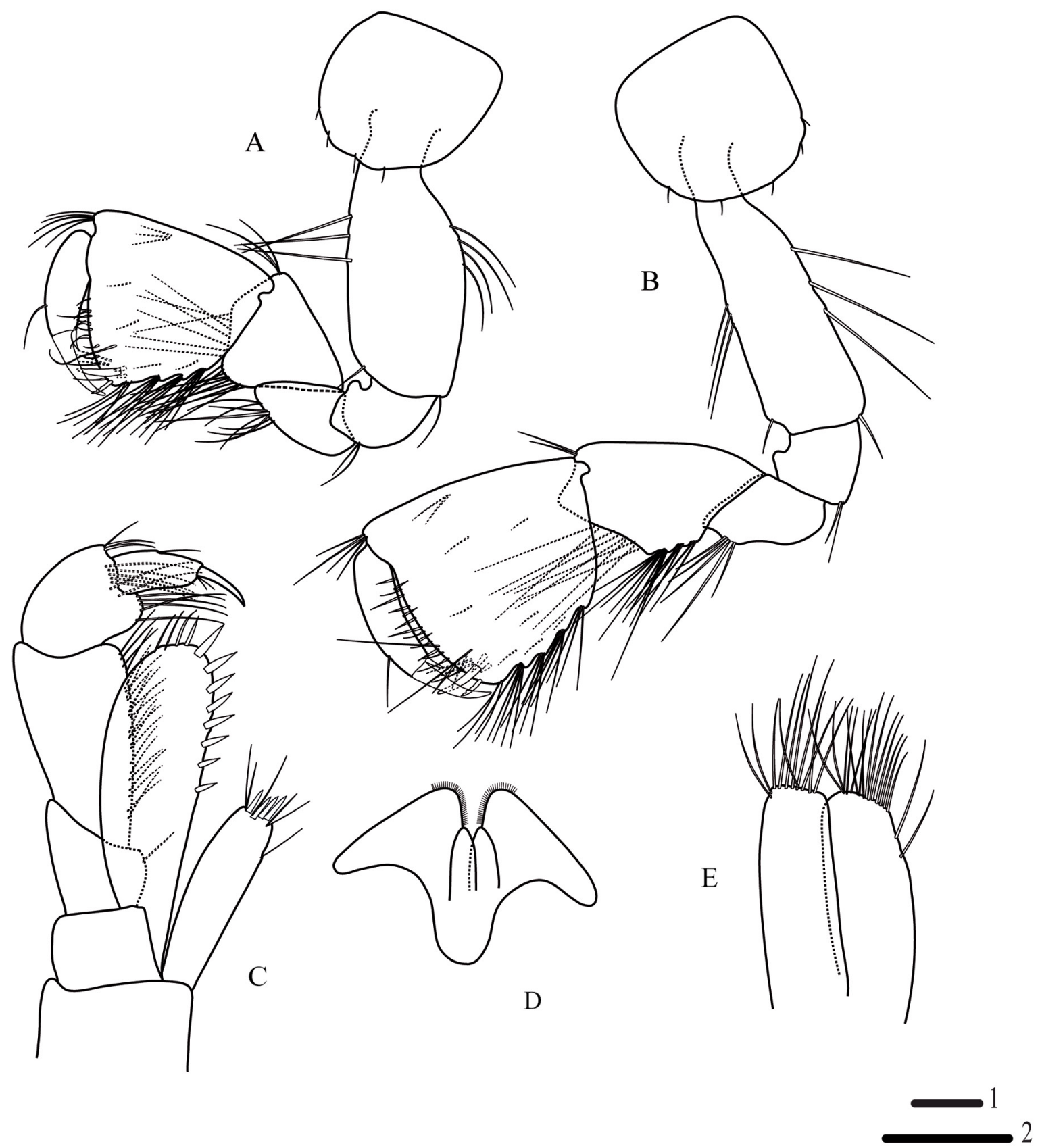

Fig. 8. Niphargus fiseri sp. nov., holotype, $\hat{O}, 8 \mathrm{~mm}$ (ZCRU Amph.1073). A. Gnathopod I. B. Gnathopod II. C. Maxilliped. D. Labium. E. Maxilla II. Scale bars: $1=0.5 \mathrm{~mm}(\mathrm{C}-\mathrm{E}) ; 2=1 \mathrm{~mm}$ (A-B). 


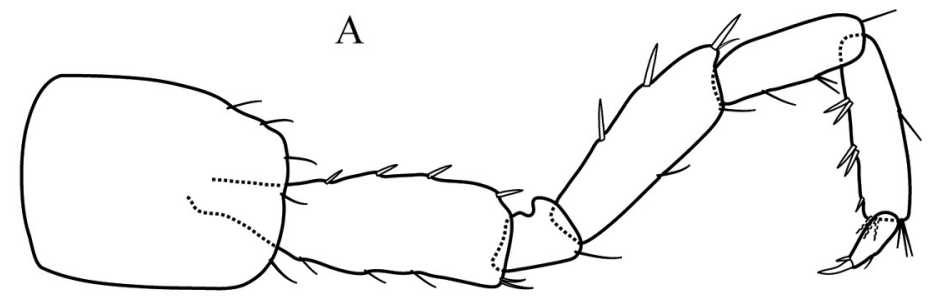

B
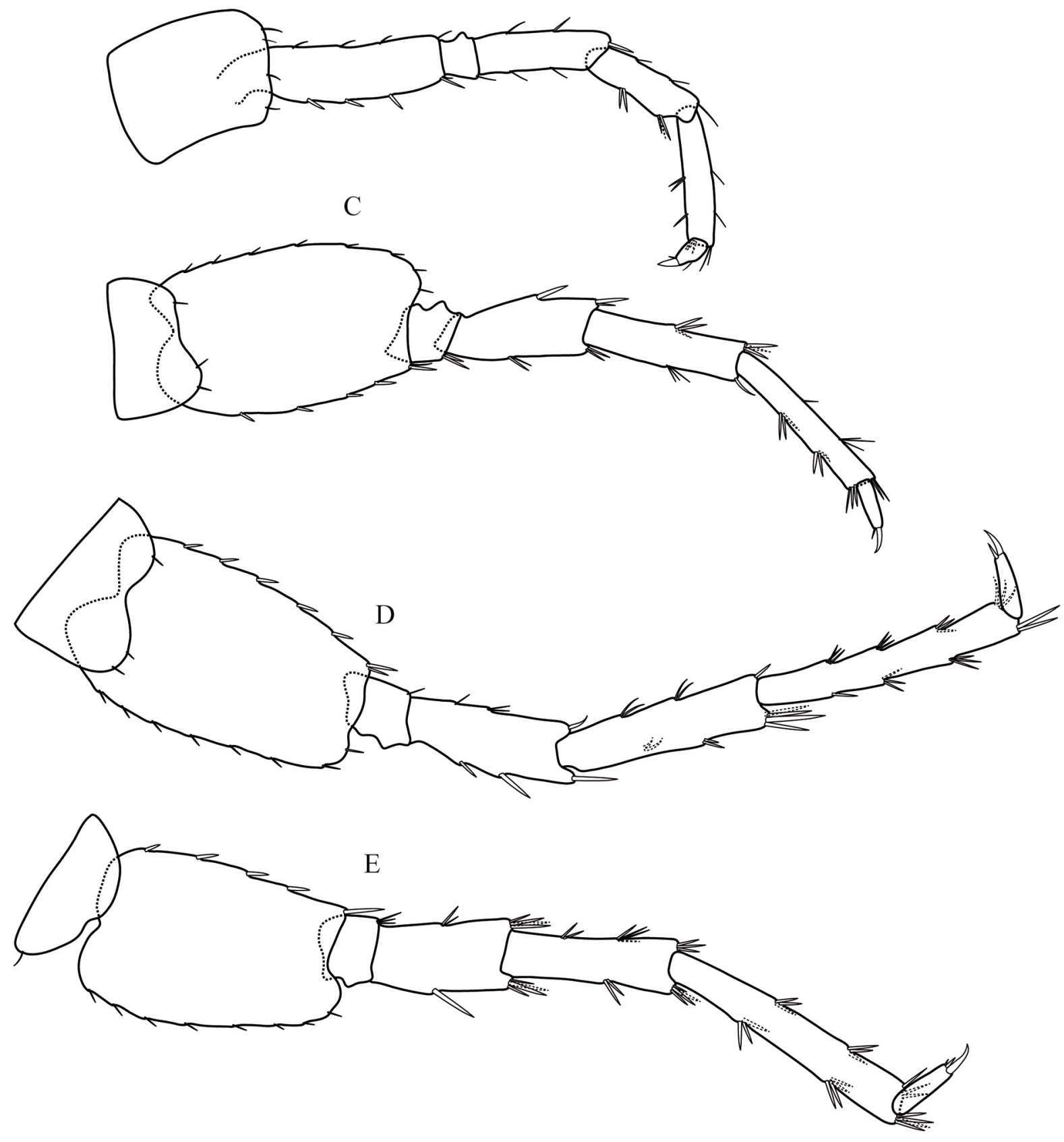

Fig. 9. Niphargus fiseri sp. nov., holotype, $\widehat{\text { O, }} 8 \mathrm{~mm}$ (ZCRU Amph.1073). A. Pereopod III. B. Pereopod IV. C. Pereopod V. D. Pereopod VI. E. Pereopod VII. Scale bar $=1 \mathrm{~mm}$. 
Pereopods. Pereopod III : IV length ratio 1.03: 1 (Fig.9A-B). Dactylus IV short, dactylus length 0.43 times propodus length, nail shorter than pedestal (Fig. 9B). Pereopods V:VI: VII length ratios 1:1.27:1.15, respectively. Pereopod VII 0.45 times body length. Pereopod bases V and VII each with five groups of spines along anterior margins and with eight setae along posterior margins, respectively (Fig. 9C, E). Pereopod base VI with six groups of spines along posterior margin and with eight setae along anterior margin (Fig. 9D). Postero-ventral lobe of ischium in pereopods V-VII developed. Ischium, merus and carpus in pereopods V-VII with several groups of spines and setae along anterior and posterior margins; propodus of pereopod VII longer than these in V-VI, dactyli of pereopods V-VII with one spine and one short seta at base of nail on inner margin, nail length of pereopod VII 0.50 times of total dactylus length (Fig. 9C-E).

EPIMERAl PLATES I-III (Fig. 10G). With angular postero-ventral corner, anterior and ventral margins convex; postero-ventral corners of plates I-III posteriorly with two, two and three spines and setae, respectively. Epimeral plates II-III each with two spines along of ventral margins. Peduncle of pleopods I-III with two-hooked retinacles at distal part of inner margins. Peduncle of pleopods II-III with one and two setae along of inner margin (Fig. 10A-C); rami of pleopods I-III each with five to nine articles (Fig. 10A-C).

Pereonites. Pereonites I-VII without setae. Pleonites I-III each with one seta in middle of article on dorsal margin. Urosomites I-II with one seta and two spines dorso-laterally, respectively. Urosomite III without setae. Urosomite I with one spine at base of uropod I.

UROPODS. Peduncle of uropod I with four and three large spines along dorso-lateral and dorso-medial margins, respectively. Inner ramus of uropod I longer than outer ramus (ratio 1:1.04); inner ramus with two groups of three spines laterally and five spines distally; outer ramus with two groups of three spines laterally and five spines distally (Fig. 10D). Inner ramus in uropod II longer than outer, both rami with lateral and distal long spines (Fig. 10E). Uropod III normal, almost 0.40 times body length. Peduncle of uropod III with five spines, outer ramus bi-articulated, distal 0.17 proximal articles. The proximal article of outer ramus bearing five and four groups of spines along inner and outer margins, respectively (Fig. 10F); distal article with four setae distally. Inner ramus short, with one distal spine and one lateral seta. Telson two times as long as broad, lobes slightly narrowing; each lobe with three spines distally, with one long spine and two plumose setae laterally (Fig. 10H).

\section{Female}

Unknown.

\section{Remarks}

Niphargus fiseri sp. nov. is diagnozed mainly by two characters. The first one is the presence of two supporting spines (R-setae sensu Karaman 2018) in both gnathopods, so far observed only in one species from Europe ( $N$. kenki Karaman, 1952), but it seems to be more common in Iran. This character has been reported in N. bisitunicus Esmaeili-Rineh, Sari \& Fišer, 2015 and $N$. lorestanensis Esmaeili-Rineh, 2018. However, in the latter two species, the propodi in gnathopod I are more rectangular and more elongated. The second character is the length of the nail to pedestal ratio in the dactyli of gnathopods I to II that includes more than $1 / 3$ of the dactyli in $N$. fiseri sp. nov. So far, this character has not been described in Iranian species.

\section{Discussion}

The West Azerbaijan Province is located in northwest of Iran between $35^{\circ} 58^{\prime}$ to $39^{\circ} 46^{\prime} \mathrm{N}$ and $44^{\circ} 03^{\prime}$ to $47^{\circ} 23^{\prime}$ E. The populations collected in this study showed the presence of two new species of the genus 

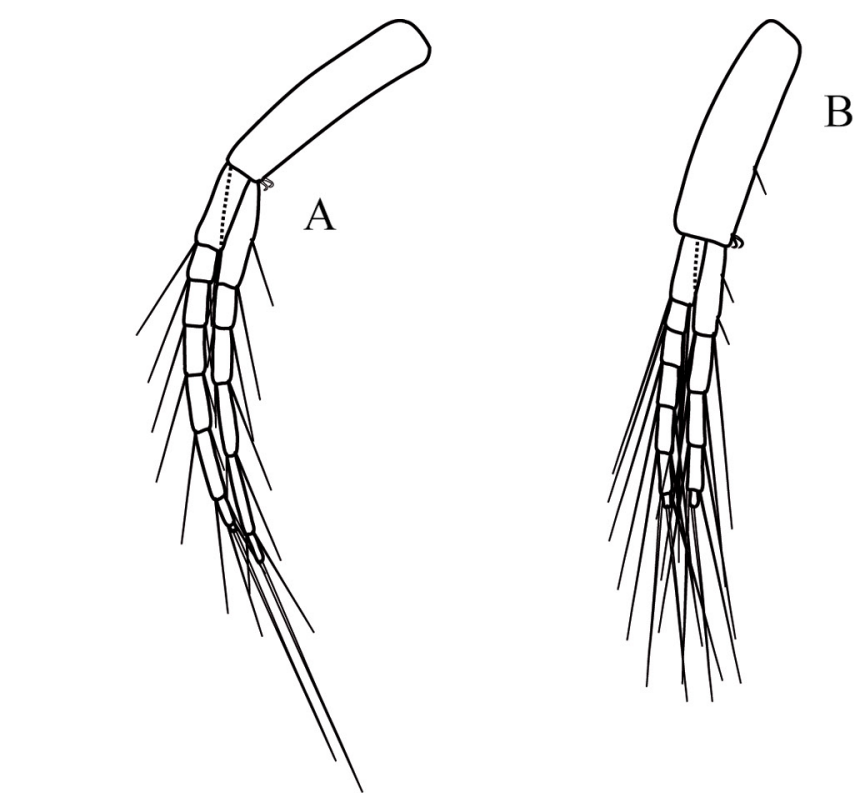

B

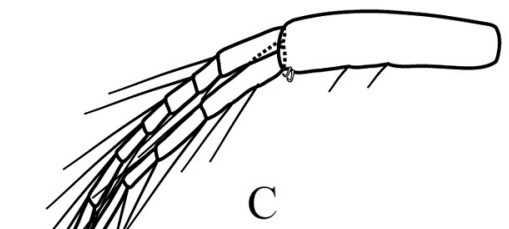

$\mathrm{D}$

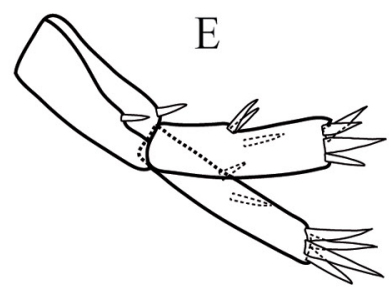

$\mathrm{C}$
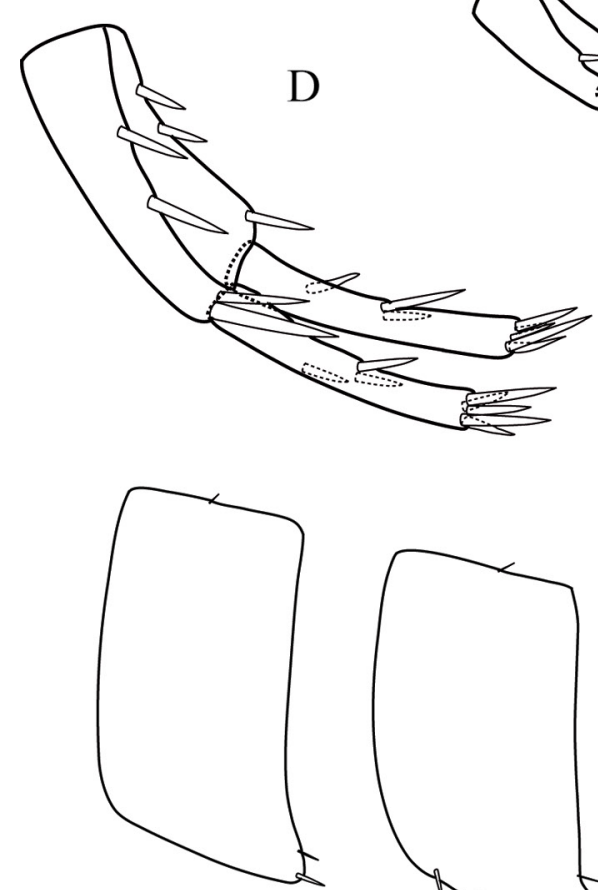

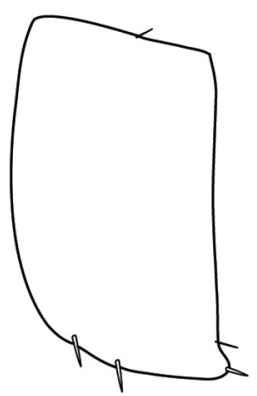

G

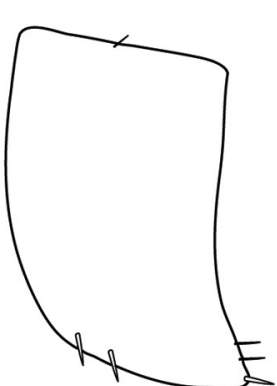

E
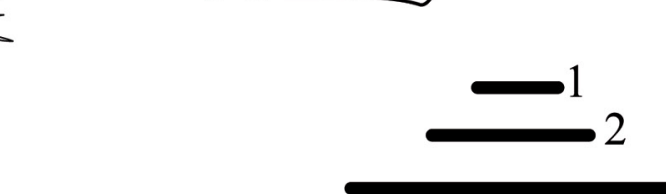

Fig. 10. Niphargus fiseri sp. nov., holotype, ô, 8 mm (ZCRU Amph.1073). A. Pleopod I. B. Pleopod II. C. Pleopod III. D. Uropod I. E. Uropod II. F. Uropod III. G. Epimeral plates. H. Telson. Scale bars: $1=0.5 \mathrm{~mm}(\mathrm{G}-\mathrm{H}) ; 2=1 \mathrm{~mm}(\mathrm{~A}-\mathrm{E}) ; 3=2 \mathrm{~mm}(\mathrm{~F})$. 
Niphargus. The DNA sequences confirmed the related taxonomic position of $N$. urmiensis sp. nov. and $N$. fiseri sp. nov. The Bayesian analysis showed that the two new species are phylogenetically different from other related species.

Genetically, based on COI and 28S rDNA genes (Table 1), N. urmiensis sp. nov. and N. alisadri are the most similar species to $N$. fiseri sp. nov. Niphargus fiseri sp. nov. resembles $N$. alisadri in terms of equal length of the maxillar palpus to the outer plate in maxilla I and the number of distal spines on the telson lobes (each with three distal spines). However, epimeral plates I-III are inclined in N. fiseri sp. nov. and there is a lower number of spines on the ventral margin of epimeral plates II-III. In comparison, $N$. alisadri bears pointed epimeral plates I-III with more spines on the ventral margin of epimeral plates II-III. The gnathopods in N. alisadri bear rectangular- to triangular-shaped propodi, but these structures in $N$. fiseri sp. nov. are trapezoidal-shaped. Moreover, N. fiseri sp. nov. is separated from N. alisadri in terms of the number of spines and simple setae on the dorso-lateral surface of urosomites I-III. Also, $N$. fiseri sp. nov. bears one lateral spine in each telson lobe, but there are two lateral spines in $N$. alisadri (Esmaeili-Rineh \& Sari 2013).

Nevertheless, $N$. urmiensis sp. nov. and $N$. fiseri sp. nov. share several morphological features regarding the number of spines on the outer surface of the palmar corner in gnathopods I-II propodi (each with one spine), the number of distal spines in the telson lobes (each with three spines), the longer size of the inner to outer ramus in uropod I, and reaching the dactyli at the posterior margin of gnathopods I-II propodi. However, $N$. urmiensis sp. nov. differs from $N$. fiseri sp. nov. in a number of features, such as the absence of lateral spines on the telson: there is one lateral spine in each telson lobe in $N$. fiseri sp. nov. Outer plate to palpus ratio in maxilla I is shorter in $N$. urmiensis sp. nov. compared with $N$. fiseri sp. nov.

In $N$. fiseri sp. nov., epimeral plates I-III are inclined whereas $N$. urmiensis sp. nov. has partly angular epimeral plate I-III. Also, multiple spines were observed in $N$. fiseri sp. nov. on the medial surface of the palmar corner (two supporting spines), a feature which was not observed in N. urmiensis sp. nov. The mentioned feature has been reported so far from one species in Europe (N. kenki) only, but it seems to be more common in Iran (Esmaeili-Rineh et al. 2015b, 2016, 2017b). The shape of gnathopod II is highly different between the two species. The propodi of $N$. fiseri sp. nov. are broader, whereas those in $N$. urmiensis sp. nov. are more rectangular and longer. The two new species differ in terms of the number of spines and simple setae on the dorso-lateral urosomites I-III margin.

These differences developed when the amphipod species become reproductively isolated (Fišer et al. 2017). In addition to the morphological distinctiveness, the molecular divergence further supported the hypothesis that $N$. urmiensis sp. nov. and $N$. fiseri sp. nov. deserve an independent species status.

\section{Acknowledgements}

This project was financially supported by Razi University as a part of the MSc thesis of first author. Special thanks go to Dr. Vahid Akmali for his help regarding molecular analyses. We are especially grateful to two anonymous referees for their valuable comments.

\section{References}

Asmyhr M., Linke S., Hose G. \& Nipperess D. 2014. Systematic conservation planning for groundwater ecosystems using phylogenetic diversity. PLoS ONE 9 (12): e115132.

https://doi.org/10.1371/journal.pone.0115132

Astrin J.J. \& Stüben P.E. 2008. Phylogeny in cryptic weevils: molecules, morphology and new genera of Western Palaearctic Cryptorhynchinae (Coleoptera: Curculionidae). Invertebrate Systematics 22 (5): 503-522. https://doi.org/10.1071/IS07057 
Brad T., Fišer C., Flot J-F. \& Sarbu S.M. 2015. Niphargus dancaui sp. nov. (Amphipoda, Niphargidae) a new species thriving in sulfidic groundwaters in southeastern Romania. European Journal of Taxonomy 164: 1-28. https://doi.org/10.5852/ejt.2015.164

Castany G. 1982. Principes et méthodes de l'hydrogéologie. Dunod Université, Paris.

Deharveng L., Stoch F., Gibert J., Bedos A., Galassi D., Zagmajster M., Brancelj A., Camacho A., Fiers F., Martin P., Giani N., Magniez G. \& Marmonier P. 2009. Groundwater biodiversity in Europe. Freshwater Biology 54: 709-726. https://doi.org/10.1111/j.1365-2427.2008.01972.x

Eme D., Zagmajster M., Delić T. \& Malard F. 2017. Do cryptic species matter in macroecology? Sequencing European groundwater crustaceans yields smaller ranges but does not challenge biodiversity determinants. Ecography 41 (2): 424-436. https://doi.org/10.1111/ecog.02683

Esmaeili-Rineh S. 2018. A new data of freshwater amphipods of genus Niphargus Schiödte, 1849 from Lorestan Province in Iran. Zootaxa 4531 (2): 242-250. https://doi.org/10.11646/zootaxa.4531.2.5

Esmaeili-Rineh S. \& Sari A. 2013. Two new species of Niphargus Schiödte, 1849 (Crustacea: Amphipoda: Niphargidae) from two caves in Iran. Journal of Natural History 47: 2649-2669.

https://doi.org/10.1080/00222933.2013.802041

Esmaeili-Rineh S., Sari A. \& Fišer C. 2015a. Making future taxonomy of Niphargus (Crustacea: Amphipoda: Niphargidae) in the Middle East easier: DELTA database of Middle East species with description of four new species from Iran. Zootaxa 4020: 401-430.

https://doi.org/10.11646/zootaxa.4020.3.1

Esmaeili-Rineh S., Sari A., Delić T., Moškrič A. \& Fišer C. 2015b. Molecular phylogeny of the subterranean genus Niphargus (Crustacea: Amphipoda) in the Middle East: a comparison with European niphargids. Zoological Journal of the Linnaean Society 175: 812-826. https://doi.org/10.1111/zoj. 12296

Esmaeili-Rineh S., Heidari F., Fišer C. \& Akmali V. 2016. Description of new endemic species of the genus Niphargus Schiödte, 1849 (Amphipoda: Niphargidae) from a karst spring in Zagros Mountains in Iran. Zootaxa 4126: 338-350. https://doi.org/10.11646/zootaxa.4126.3.2

Esmaeili-Rineh S., Mirghaffari S.A. \& Sharifi M. 2017a. The description of a new species of Niphargus from Iran based on morphological and molecular data. Subterranean Biology 22: 43-58.

https://doi.org/10.3897/subtbiol.22.11286

Esmaeili-Rineh S., Sari A. Fišer C. \& Bargrizaneh Z. 2017b. Completion of molecular taxonomy: description of four amphipod species (Crustacea: Amphipoda: Niphargidae) from Iran and release of database for morphological taxonomy. Zoologischer Anzeiger 271: 57-79.

https://doi.org/10.1016/j.jcz.2017.04.009

Fišer C., Zakšek V., Zagmajster M. \& Sket B. 2007. Taxonomy and biogeography of Niphargus steueri (Crustacea: Amphipoda). Limnology 8: 297-309. https://doi.org/10.1007/s10201-007-0221-5

Fišer C., Çamur-Elipek B. \& Özbek M. 2009a. The subterranean genus Niphargus (Crustacea, Amphipoda) in the Middle East: a faunistic overview with descriptions of two new species. Zoologischer Anzeiger 248: 137-150. https://doi.org/10.1016/j.jcz.2009.03.003

Fišer C., Trontelj P., Luštrik R. \& Sket B. 2009b. Toward a unified taxonomy of Niphargus (Crustacea: Amphipoda): a review of morphological variability. Zootaxa 2061: 1-22.

https://doi.org/10.11646/zootaxa.2061.1.1

Fišer C., Konec M., Alther R., Švara V. \& Altermatt F. 2017. Taxonomic, phylogenetic and ecological diversity of Niphargus (Amphipoda: Crustacea) in the Hölloch cave system (Switzerland). Systematics and Biodiversity 15: 218-237. https://doi.org/10.1080/14772000.2016.1249112 
Frey W. \& Probst P. 1986. A synopsis of the vegetation of Iran In: Kiirschner H. (ed) Contributions to the Vegetation of Southwest Asia: 9-43. Dr. Ludwig Reichert Verlag. Wiesbaden.

Glanville K., Schulz C., Tomlinson M. \& Butler D. 2016. Biodiversity and biogeography of groundwater invertebrates in Queensland, Australia. Subterranean Biology 17: 55-76.

https://doi.org/10.3897/subtbiol.17.7542

Hall T.A. 1999. BioEdit: a user-friendly biological sequence alignment editor and analysis program for Windows 95/98/NT. Nucleic Acids Symposium Series 41: 95-98.

Humphreys W.F. 2006. Groundwater fauna. Australian State of the Environment Committee, Department of the Environment and Heritage, Canberra.

Jörger K.M. \& Schrödl M. 2013. How to describe a cryptic species? Practical challenges of molecular taxonomy. Frontiers in Zoology 10 (1): 59. https://doi.org/10.1186/1742-9994-10-59

Karaman S. 1952. Podrod Stygoniphargus u Sloveniji i Hrvatskoj, Poseban otisak iz 25. knjige Prirodoslovnih istraživanja. Academia Scientiarum et Artium Slavorum Meridionalium 1: 5-38.

Karaman G.S. 1998. First discovery of the family Niphargidae (Gammaridea) in Iran (Contribution to the knowledge of the Amphipoda 234). Glas Od Prir Nauka-Crnog Akad Nauka Umjet 12: 9-22.

Karaman G.S. 2018. Further discovery of new or partially known taxa of the genus Niphargus Schiödte, 1849 (fam. Niphargidae) in Greece (Contribution to the knowledge of the Amphipoda 302). Agriculture and Forestry 64 (2): 5-31.

Kimura M. 1980. A simple method for estimating evolutionary rate of base substitutions through comparative studies of nucleotide sequences. Journal of Molecular Evolution 16: 111-120.

https://doi.org/10.1007/BF01731581

Madjnoonian H., Kiabi B.H. \& Danesh M. 2005. Readings in Zoogeography of IraN. Part I. Department of Environment, Iran.

Mamaghani-Shishvan M., Esmaeili-Rineh S. \& Fišer C. 2017. An integrated morphological and molecular approach to a new species description of amphipods in the Niphargidae from two caves in west of Iran. Zoological Studies 56: 33. https://doi.org/10.6620/ZS.2017.56-33

Posada D. 2008. jModelTest: Phylogenetic model averaging. Molecular Biology and Evolution 25: 1253-1256. https://doi.org/10.1093/molbev/msn083

Raeisi E. 2004. Iran cave and karst. In: Gunn J. (ed.) Encyclopedia of Cave and Karst: 460-461. Fitzroy Dearborn, New York.

Rambaut A. \& Drummond A.J. 2009. Bayesian Evolutionary Analysis Sampling Trees (BEAST). Version 1.7.4.

Ronquist F. \& Huelsenbeck J.P. 2003. MrBayes 3: Bayesian phylogenetic inference under mixed models. Bioinformatics 19: 1572-1574. https://doi.org/10.1093/bioinformatics/btg180

Stokkan M., Jurado-Rivera J.A., Oromí P., Juan C., Jaume D. \& Ponsa J. 2018. Species delimitation and mitogenome phylogenetics in the subterranean genus Pseudoniphargus (Crustacea: Amphipoda). Molecular Phylogenetic and Evolution 127: 988-999. https://doi.org/10.1016/j.ympev.2018.07.002

Tamura K., Peterson D., Peterson N., Stecher G., Nei M. \& Kumar S. 2011. MEGA5: Molecular Evolutionary Genetics Analysis using Maximum Likelihood, Evolutionary Distance, and Maximum Parsimony Methods. Molecular Biology and Evolution 28: 2731-2739.

https://doi.org/10.1093/molbev/msr121 
Thompson J.D., Higgins D.G. \& Gibson T. 1994. Clustal W: improving the sensitivity of progressive multiple sequence alignment through sequence weighting, position-specific gap penalties and weight matrix choice. Nucleic Acids Research 22: 4673-4680. https://doi.org/10.1093/nar/22.22.4673

Väinölä R., Witt J.D.S., Grabowski M., Bradbury J.H., Jazdzewski K. \& Sket B. 2008. Global diversity of amphipods (Amphipoda; Crustacea) in freshwater. Hydrobiologia 595: 241-255.

https://doi.org/10.1007/s10750-007-9020-6

Verovnik R., Sket B. \& Trontelj P. 2005. The colonization of Europe by the freshwater crustacean Asellus aquaticus (Crustacea: Isopoda) proceeded from ancient refugia and was directed by habitat connectivity. Molecular Ecology 14: 4355-4369. https://doi.org/10.1111/j.1365-294X.2005.02745.x

White W.B. 2007. Groundwater flow in karstic aquifers. In: Delleur J.W. (ed.) The Handbook of Groundwater Engineering. $2^{\text {nd }}$ edition 21: 1-47. CRC Press \& Taylor and Francis Group.

Witt J.D.S., Threloff D.L. \& Hebert P.D.N. 2006. DNA barcoding reveals extraordinary cryptic diversity in an amphipod genus: implications for desert spring conservation. Molecular Ecology 15: 3073-3082. https://doi.org/10.1111/j.1365-294X.2006.02999.x

Zakšek V., Sket B. \& Trontelj P. 2007. Phylogeny of the cave shrimp Troglocaris: evidence of a young connection between Balkans and Caucasus. Molecular Phylogenetics and Evolution 42: 223-235.

https://doi.org/10.1016/j.ympev.2006.07.009

Manuscript received: 24 January 2019

Manuscript accepted: 1 July 2019

Published on: 27 August 2019

Topic editor: Rudy Jocqué

Desk editor: Pepe Fernández

Printed versions of all papers are also deposited in the libraries of the institutes that are members of the EJT consortium: Muséum national d'Histoire naturelle, Paris, France; Meise Botanic Garden, Belgium; Royal Museum for Central Africa, Tervuren, Belgium; Royal Belgian Institute of Natural Sciences, Brussels, Belgium; Natural History Museum of Denmark, Copenhagen, Denmark; Naturalis Biodiversity Center, Leiden, the Netherlands; Museo Nacional de Ciencias Naturales-CSIC, Madrid, Spain; Real Jardín Botánico de Madrid CSIC, Spain; Zoological Research Museum Alexander Koenig, Bonn, Germany; National Museum, Prague, Czech Republic. 